\title{
Keanekaragaman dan Sebaran Mikroba Endofit Indigenous Pada Tanaman Kedelai (Glycine max (L.) Merril)
}

\author{
Author(s): Fitra Parlindo*(1); Erfan Dani Septia(1) \\ (1) Universitas Muhammadiyah Malang \\ * Corresponding author:erfandani@umm.ac.id
}

\begin{abstract}
ABSTRAK
Penelitian ini bertujuan untuk mengetahui keanekaragaman mikroba endofit indigenous pada berbagai bagian jaringan tanaman kedelai dan menguji virulensinya secara in vitro. Penelitian ini menggunakan metode eksplorasi. Hasil eksplorasi cendawan endofit indigenous berjumlah 11 isolat dan bakteri berjumlah 3 isolat. Cendawan endofit indigenous berhasil diisolasi dari seluruh jaringan tanaman, kecuali polong. Keragaman cendawan endofit indigenous tertinggi terdapat pada jaringan akar dan batang, yaitu masing-masing berjumlah 4 isolat. Identitas cendawan endofit indigenous yang berhasil diidentifikasi antara lain adalah Fusarium sp., Verticilllum sp., Alternaria sp., Aspergillus sp., dan Penicillium sp. Adapun 6 isolat lainnya tidak dapat terindentifikasi. Bakteri endofit indigenous hanya terisolasi dari jaringan polong, akar, dan tanah. Seluruh bakteri merupakan golongan bakteri Gram negatif. Berdasarkan hasil Uji Hipovirulensi, terhadap 7 isolat cendawan endofit indigenous yang masuk dalam kategori hipovirulen dan 4 isolat lainnya bersifat virulen. Sedangkan semua isolat bakteri endofit indigenous yang diuji menunjukkan kategori virulen.
\end{abstract}

\section{Kata Kunci:}

Endofit;

Kedelai;

Mikroba;

Keywords: $\quad$ The high demand for soybean commodities is in line with the increasing public This study

Soybeans; aims to determine the diversity of indigenous endophytic microbes in various parts of

Microbes; soybean tissue and examine the virulence in vitro method. This study used an exploration

Microbes, method. The results of the exploration of indigenous endophytic fungi amounted to 11

Endophytic; isolates and bacteria totaling 3 isolates. Indigenous endophytic fungi were isolated from all plant tissues, except pods. The highest diversity of indigenous endophytic fungi was found in root and stem tissues, which are 4 isolates respectively. The identities of indigenous endophytic fungi that were successfully identified were Fusarium sp., Verticilllum sp., Alternaria sp., Aspergillus sp., and Penicillium sp. The other 6 isolates cannot be identified. Indigenous endophytic bacteria were only isolated from pods, roots and soil tissue. All bacteria were Gram negative bacteria. Based on the results of the hypovirulence test, 7 isolates of indigenous endophytic fungi were included in the hypovirulent category and 4 other isolates were virulent. While all indigenous endophytic bacterial isolates showed a virulent category. 


\section{PENDAHULUAN}

Kedelai (Glycine max (L.) Merril) adalah salah satu tanaman pangan yang sangat populer di dunia, termasuk di Indonesia. Permintaan yang tinggi terhadap komoditas ini seiring dengan peningkatan konsumsi masyarakat pada produk-produk olahannya. Kenyataan tersebut tidak diimbangi dengan peningkatan produktivitas kedelai dalam negeri. Riniarsi (2016) melaporkan bahwa produktivitas kedelai tahun 2016 bahkan mengalami penurunan sebesar $3.95 \%$ dibandingkan tahun sebelumnya.

Satu dari beberapa faktor yang menyebabkan penurunan produksi kedelai yaitu karena penyakit yang disebabkan oleh virus tanaman. Pencegahan dan penanganan yang terlambat mengakibatkan kerugian tidak dapat dihindari. Seiring dengan tren pengurangan bahan kimia sintetis pada praktik budidaya tanaman, aplikasi mikroba endofit indigenous menjadi solusi alternatif dalam pengendalian penyakit yang disebabkan oleh virus tanaman. Berg (2009) menyatakan bahwa mikroba endofit biasanya hidup di dalam jaringan tanaman yang sama dengan bakteri atau jamur penyebab penyakit sehingga sangat cocok dijadikan sebagai agen pengendali hayati. Yulianti (2012) melaporkan bahwa mikroba endofit secara alami merupakan bagian dari tanaman sehat. Oleh karena itu, endofit didefinisikan sebagai mikroorganisme yang hidup di dalam jaringan tanaman tanpa menimbulkan efek negatif. Mikroba endofit indigenous artinya adalah mikroba endofit yang berasal dari dalam jaringan tanaman itu sendiri, umumnya terdiri atas golongan cendawan dan bakteri.

Penelitian ini bertujuan untuk mengetahui keanekaragaman mikroba endofit indigenous pada berbagai bagian jaringan tanaman kedelai dan menguji virulensinya secara in vitro.

\section{METODOLOGI}

Penelitian ini dilakukan selama empat bulan, dari Januari hingga April 2018 di Laboratorium Bioteknologi dan Laboratorium Biomed Fakultas Kedokteran UMM. Bahan yang digunakan yakni media PDA dan NA, alkohol $70 \%$, $\mathrm{MgCl}_{2}$, methanol, dan akuades steril. Tanaman yang dieksplorasi adalah 5 sampel tanaman kedelai sehat berumur 65 hari yang diambil acak di kebun percobaan Balai Penelitian Tanaman Aneka Kacang dan Umbi Malang.

Kegiatan isolasi cendawan dimulai dengan sterilisasi bagian tanaman (akar, batang, daun, polong, serta tanah sekitar perakaran). Bagian tanaman yang telah diambil dibersihkan dengan mencucinya pada air mengalir. Bagian tanaman dipotong $1 \mathrm{~cm}$ lalu direndam alkohol 70\% selama satu menit. Potongan bagian tanaman direndam lagi dengan larutan $\mathrm{MgCl}_{2}$ selama satu menit, kemudian mencucinya dengan akuades steril selama satu menit, lalu mengeringkannya dengan tisu steril. Tiap-tiap pencucian dilakukan dengan dua kali ulangan. Bagian jaringan tanaman tersebut selanjutnya ditanam pada media PDA yang telah disiapkan. Proses inkubasi dilakukan selama tujuh hari hingga munculnya koloni. Purifikasi dilakukan demi mendapatkan biakan murni dengan cara memindahkan miselium yang tumbuh ke cawan petri yang telah berisi media PDA. Sanjaya et al. (2010) menyatakan bahwa setelah diperoleh kultur murni, masing-masing isolat ditanam pada cawan yang telah berisi medium agar. Sebanyak satu ose dari masing-masing isolat diletakkan dalam tiga titik pada permukaan medium agar. Selanjutnya, cawan diberi label dan diinkubasi selama 5-7 hari. Adapun identifikasi cendawan dilakukan berdasarkan penampakan mikroskopis. Identifikasi mikroskopis cendawan disesuaikan dengan buku identifikasi (Barnett \& Hunter, 1998). 
Isolasi bakteri dimulai dengan sterilisasi bagian jaringan tanaman. Setiap bagian tanaman dicuci dengan air mengalir, lalu direndam alkohol $70 \%$ dan larutan $\mathrm{MgCl}_{2}$, masing-masing selama satu menit. Selanjutnya mencucinya dengan akuades steril selama satu menit dan mengeringkannya dengan tisu steril. Perendaman atau pencucian dilakukan dengan dua kali ulangan. Tiap bagian tanaman kedelai dihaluskan dengan larutan methanol $70 \%$ dan disentrifugasi dengan kecepatan 4000 rpm selama 10 menit untuk memisahkan natan dan supernatan. Selanjutnya, supernatan sebanyak $10 \mu 1$ dipindahkan ke dalam cawan petri yang telah berisi media NA. Purifikasi bakteri dilakukan dengan memindahkan koloni bakteri yang telah tumbuh ke dalam cawan petri berisi media NA dengan metode zigzag. Adapun identifikasi bakteri dilakukan berdasarkan penampakan makroskopis dan mikroskopis. Identifikasi makroskopis bakteri disesuaikan dengan metode pewarnaan Gramm, sedangkan identifikasi mikroskopis berdasarkan morfologi bakteri.

Tahap selanjutnya adalah uji hipovirulensi yang dilakukan pada benih tanaman mentimun, karena tanaman ini dapat memberikan respon yang cepat terhadap serangan patogen. Metode yang digunakan yaitu menurut Worosuryani et al. (2006) dengan modifikasi. Permukaan benih mentimun disterilkan alkohol $70 \%$ selama satu menit, clorox $2 \%$ selama 30 detik, lalu dibilas akuades sebanyak tiga kali, lalu dikering-anginkan. Isolat murni cendawan ditanam pada media PDA dalam botol kultur dan diinkubasi selama tiga hari. Selanjutnya, tiga benih mentimun ditanam pada tiap biakan cendawan tersebut dan diinkubasi 14 hari. Sedangkan untuk bakteri, tiga benih mentimun direndam dalam suspensi tiap bakteri selama 2 jam dan ditanam pada media NA dalam botol kultur, lalu diinkubasi 14 hari. Kontrol dibuat dengan menaman benih pada media tanpa penambahan cendawan dan bakteri endofit. Pertumbuhan benih mentimun diamati setiap hari. Indeks keparahan penyakit pada hasil perkecambahan mentimun dideterminasikan dengan skor individual hasil modifikasi Worosuryani et al. (2006) sebagai berikut:

$\mathrm{DSI}=\frac{\sum \mathrm{N}}{\mathrm{Z}}$

Keterangan :

DSI = Disease Severity Index (Indeks Keparahan Penyakit)

$\mathrm{N}$ = Nilai tingkat keparahan penyakit masingmasing individu

$\mathrm{Z}=$ Jumlah individu yang digunakan

Nilai Tingkat keparahan penyakit:

$0=$ Sehat dan tidak ada infeksi pada hipokotil,

$1=$ Satu atau dua bercak coklat muda $<0,25 \mathrm{~cm}$,

$2=$ Bercak coklat muda $<0,5 \mathrm{~cm}$ dan area kebasahan $<10 \%$ pada hipokotil,

3 = Bercak coklat muda sampai tua $>1,0 \mathrm{~cm}$ dan kemudian bergabung dengan bercak lainnya dan daerah kebasahan $10 \%<\mathrm{x}<100 \%$ pada hipokotil (daun belum layu dan hipokotil masih tegar dan putih,

4 = Hipokotil bercak hitam, daun layu, dan bibit mati.

Worosuryani et al. (2006) melaporkan isolat yang tidak menyebabkan gejala penyakit atau menunjukkan sedikit gejala $(\mathrm{DSI}<2,0)$ pada perkecambahan mentimun dikategorikan sebagai isolat hipovirulen. Sneh et al. (2004) juga mengklasifikasikan virulensi isolat cendawan atas lima kategori berdasarkan nilai DSI dan gejalanya. Isolat dengan nilai DSI $0-0.3$ dikategorikan sebagai isolat tidak virulen atau bersifat hipovirulen. Nilai DSI 0.4-0.9 dengan kategori virulensi rendah, 1-1.9 dengan kategori moderat, 2-2.9 dengan kategori virulen, dan 3-4 dengan kategori sangat virulen. 


\section{HASIL DAN PEMBAHASAN \\ Eksplorasi dan Karakterisasi Mikroba Endofit Indigenous}

Mikroba endofit indigenous yang berhasil dieksplorasi dari tanaman kedelai sehat varietas Gepak Kuning asal kebun percobaan Balai Penelitian Tanaman Aneka Kacang dan Umbi Malang ditunjukkan pada Tabel 1.

Tabel 1. Hasil Eksplorasi Mikroba Endofit Indigenous dari tanaman kedelai

\begin{tabular}{lcc}
\hline Jaringan Asal & \multicolumn{2}{c}{ Jenis Mikroba Endofit } \\
\cline { 2 - 3 } $\begin{array}{l}\text { Mikroba } \\
\text { Endofit }\end{array}$ & $\begin{array}{c}\text { Cendawan } \\
\text { (isolat) }\end{array}$ & $\begin{array}{c}\text { Bakteri } \\
\text { (isolat) }\end{array}$ \\
\hline Akar & 4 & 1 \\
Batang & 4 & - \\
Daun & 2 & - \\
Polong & - & 1 \\
Tanah & 1 & 1 \\
\hline Jumlah & 11 & 3 \\
\hline
\end{tabular}

\section{A. Karakterisasi dan Identifikasi Cendawan Endofit Indigenous}

Cendawan endofit indigenous yang berhasil dieskplorasi berjumlah 11 isolat yang berasal dari bagian akar, batang, daun, dan tanah. Isolat cendawan tersebut diberi kode yang diawali dengan huruf CK (cendawan kedelai) lalu diikuti oleh kode asal jaringan dan nomor. Karakter makroskopis diamati 7 hari setelah inkubasi (HSI). Karakter yang diamati yakni pola sebaran miselium, warna koloni di atas dan bawah permukaan media, kecepatan pertumbuhan miselium memenuhi permukaan media agar (HSI), dan tekstur koloni. Karakter makroskopis isolat cendawan endofit disajikan pada Tabel 2.

Tabel 2. Karakteristik morfologi cendawan endofit indigenous secara makroskopis

\begin{tabular}{|c|c|c|c|c|c|}
\hline $\begin{array}{l}\text { Asal } \\
\text { Jaringan }\end{array}$ & $\begin{array}{l}\text { Kode } \\
\text { Isolat }\end{array}$ & $\begin{array}{l}\text { Pola Sebaran } \\
\text { Miselium }\end{array}$ & $\begin{array}{c}\text { Warna Koloni } \\
\text { (Atas - Bawah) }\end{array}$ & $\begin{array}{l}\text { Kecepatan } \\
\text { Pertumbuhan } \\
\text { Miselium }\end{array}$ & Tekstur Koloni \\
\hline \multirow{4}{*}{ Akar } & CKA1 & Konsentris & Putih Merah - Putih & $6 \mathrm{HSI}$ & $\begin{array}{l}\text { Seperti kapas dan } \\
\text { granular }\end{array}$ \\
\hline & CKA2 & Konsentris & Putih - Coklat Muda & $11 \mathrm{HSI}$ & Kasar dan tipis \\
\hline & CKA3 & Konsentris & $\begin{array}{l}\text { Putih Kuning - } \\
\text { Coklat muda }\end{array}$ & $6 \mathrm{HSI}$ & Halus seperti kapas \\
\hline & CKA4 & Konsentris & $\begin{array}{c}\text { Abu abu Kehitaman - } \\
\text { Hitam }\end{array}$ & 5 HSI & Halus seperti kapas \\
\hline \multirow{4}{*}{ Batang } & CKB1 & Radial & $\begin{array}{l}\text { Putih Kecoklatan - } \\
\text { Coklat tua }\end{array}$ & $6 \mathrm{HSI}$ & Granular dan kompak \\
\hline & CKB2 & Konsentris & Putih - Coklat & $10 \mathrm{HSI}$ & $\begin{array}{l}\text { Seperti kapas dan } \\
\text { granular }\end{array}$ \\
\hline & CKB3 & Konsentris & $\begin{array}{c}\text { Putih Kecoklatan - } \\
\text { Hitam } \\
\end{array}$ & $6 \mathrm{HSI}$ & Kasar dan tipis \\
\hline & CKB4 & Konsentris & Putih - Hitam & $6 \mathrm{HSI}$ & Kasar dan tipis \\
\hline \multirow[b]{2}{*}{ Daun } & CKD1 & Konsentris & Putih - Putih & $3 \mathrm{HSI}$ & Halus seperti kapas \\
\hline & CKD2 & Konsentris & Putih - Abu-abu & $3 \mathrm{HSI}$ & $\begin{array}{l}\text { Seperti kapas dan } \\
\text { tebal }\end{array}$ \\
\hline Tanah & CKT & Konsentris & Hijau Putih - Hijau & $12 \mathrm{HSI}$ & $\begin{array}{c}\text { Seperti kapas dan } \\
\text { granular }\end{array}$ \\
\hline
\end{tabular}

Berdasarkan pola sebaran miselium, diperoleh dua jenis morfospesies yang berbeda yaitu koloni cendawan yang tumbuh konsentris dan radial. Isolat cendawan yang tumbuh radial (menyebar dari pusat koloni ke arah tepi koloni) berasal dari jaringan batang, sedangkan 10 isolat lainnya memiliki miselium yang 
tumbuh dengan pola konsentris. Warna koloni cendawan endofit yang ditemukan bervariasi, tapi cenderung didominasi oleh warna putih.

Karakterisasi morfologi cendawan endofit secara mikroskopis dilakukan menggunakan fotomikroskop optilab perbesaran 40x. Karakter yang diamati yakni bentuk hifa dan konidia. Identitas cendawan endofit indigenous diamati dengan bantuan buku Identifikasi Illustrated Genera of Imperfect fungi Barnett and Hunter (1998) berdasarkan hasil karakteristik mikroskopis.

Hasil identifikasi menunjukkan bahwa terdapat 5 isolat cendawan yang berhasil diketahui identitasnya. Berdasarkan identitas tersebut, isolat cendawan indigenous bersifat parasit maupun saprofit pada tanaman. Cendawan parasit yaitu cendawan yang cara hidupnya adalah dengan memperoleh bahan organik dari inangnya (tumpangan), sedangkan cendawan saprofit menurut Sudantha (2009) adalah mikrobia yang mengambil makanan dari sisa bahan organik atau bahan mati. Adapun 6 isolat lainnya tidak dapat teridentifikasi karena tidak ditemukannya bagian-bagian lain seperti spora atau konidia yang dapat menunjukkan identitas cendawan untuk dikelompokkan ke marga tertentu. Hasil karakterisasi dan identifikasi masingmasing isolat dideskripsikan pada Gambar 1.

\begin{tabular}{ccc}
$\begin{array}{c}\text { Tabel 3. Hasil } \\
\text { Endofit }\end{array}$ & $\begin{array}{c}\text { Identifikasi } \\
\text { Indigenous }\end{array}$ & Cendawan \\
\hline Hasil Identifikasi & $\begin{array}{c}\text { Jumlah } \\
\text { (Isolat) }\end{array}$ & Keterangan \\
\hline Fusarium sp. & 1 & Isolat CKA1 \\
Verticillium sp. & 1 & Isolat CKA2 \\
Alternaria sp. & 1 & Isolat CKA4 \\
Aspergillus sp. & 1 & Isolat CKB1 \\
Penicillium sp. & 1 & Isolat CKT \\
& & Isolat CKA3, \\
& & CKB2, \\
Hifa Steril & 6 & CKB3, CKB4, \\
(Unidentified) & & CKD1, dan \\
& & CKD2 \\
\hline
\end{tabular}

\section{Cendawan Endofit Indigenous Asal Akar}
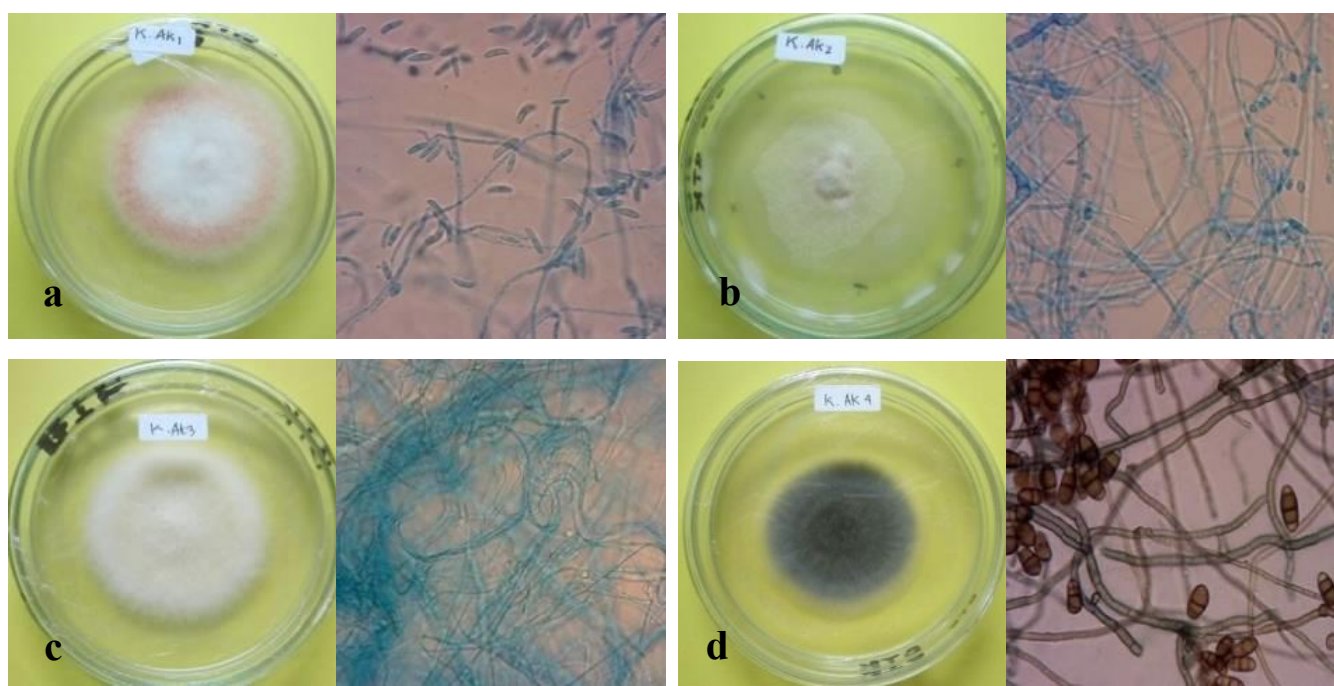

Gambar 1. Penampakan Koloni Isolat Cendawan Endofit Asal Akar: (a) Isolat CKA1, (b) Isolat CKA2, (c) Isolat CKA3, dan (d) Isolat CKA4

Isolat CKA1 mempunyai koloni dengan tekstur seperti kapas berwarna putih keunguan (Gambar 1a). Pola sebaran miseliumnya konsentris dengan 
pertumbuhan yang cepat pada 6 HSI. Struktur hifanya bersepta dan hialin dengan konidia berupa makrokonidia. Isolat yang menunjukkan ciri morfologi seperti ini diidentifikasi sebagai Fusarium sp. Cendawan Fusarium sp. juga telah berhasil diisolasi pada akar beberapa jenis kacang-kacangan. El-Maghraby et al. (2013) menemukan bahwa Fusarium adalah genus cendawan endofit yang paling dominan pada perakaran Leguminacea. Meski genus tersebut memiliki nama yang mirip dengan patogen, isolat Fusarium yang diperoleh tidak menghambat pertumbuhan tanaman bahkan beberapa isolat dapat meningkatkan pertumbuhan kacang tanah secara nyata. Istifadah and Sari (2017) juga melaporkan bahwa sebagian besar isolat yang diperoleh dari akar tanaman kacang adalah genus Fusarium.

Isolat CKA2 memiliki koloni dengan tekstur kasar dan tipis, berwarna putih, pola sebaran miselium konsentris, dan pertumbuhan miselium yang lambat pada 11 HSI. Struktur hifa yang terbentuk bersepta dan hialin, dengan konidia berupa makrokonidia. Isolat ini diidentifikasi sebagai Verticillium sp. Hardaningsih (2012) melaporkan Verticillium sp. sebagai cendawan yang bersifat parasit. Ahmad (2013) melaporkan bahwa koloni Verticillium sp. dapat tumbuh dengan sedang dan cepat pada suhu $25^{\circ} \mathrm{C}$ di media PDA. Koloni pada permukaan memiliki warna putih dan dari dasar cawan petri memperlihatkan warna putih hingga coklat (karat). Secara mikroskopis, cendawan ini mempunyai hifa yang hialin dan bersepta. Konidiofor berhialin dengan cabang atau tidak bercabang. Percabangan konidiofor terbentuk pada cincin seperti tangkai daun pada beberapa tingkatan.

Isolat CKA3 merupakan hifa steril yang memiliki koloni bertekstur halus seperti kapas dan berwarna putih kekuningan. Pola sebaran miseliumnya adalah konsentris. Terdapat kumpulan miselium yang beerwarna putih pekat di bagian tengah. Sruktur hifa isolat ini tidak bersepta dan hialin serta tidak ditemukan adanya konidia.

Isolat CKA4 mempunyai koloni bertekstur bulu halus serta berwarna abuabu kehitaman pada permukaan. Pola sebaran miselium adalah konsentris dengan pertumbuhan miselium yang cepat. Struktur hifa yang terbentuk yaitu bersepta dan tampak coklat. Konidia berbentuk oval, berukuran besar, dan berwarna coklat gelap. Isolat yang menunjukkan ciri morfologi seperti ini diidentifikasi sebagai Alternaria sp. Hasil karakterisasi ini sesuai dengan hasil penelitian Ata et al. (2016) yang mendapati karakter morfologi Alternaria sp. dengan warna hifa kecoklatan, terdapat sekat pada hifa, warna konidia yang kecoklatan dengan tipe pertumbuhan konidia yang gerombol.

Isolat CKB1 memiliki koloni berwarna putih kemudian menjadi kecoklatan, di atas koloni terdapat butiran seperti serbuk yang merupakan kepala konidia. Sebaran miselium berpola radial dengan kecepatan pertumbuhan miselium tercatat cepat, dengan sebaran yang memenuhi seluruh permukaan Media PDA pada 6 HSI. Koloninya bertekstur granular dan kompak. Struktur hifa bersepta, hialin, dengan konidia berlimpah berwarna hitam. Trizelia et al. (2017) menyatakan bahwa Aspergillus sp. memiliki reproduksi aseksual dengan memproduksi spora yang disebut konidia. Isolat ini diidentifikasi sebagai Aspergillus sp. Beberapa penelitian sebelumnya juga telah berhasil mengisolasi cendawan endofit dari jaringan batang tanaman. Waruwu et al. (2016) mendapati 8 isolat cendawan endofit tidak patogen asal batang tanaman padi. Batang tanaman merupakan bagian yang paling banyak perolehan cendawan endofitnya. Trizelia et al., (2017) berhasil mengisolasi dan memurnikan Aspergillus sp. dari batang gandum yang sehat. 
Isolat CKB2, CKB3, dan CKB4 merupakan hifa steril dengan karakteristik berbeda-beda. Koloni pada Isolat CKB2 berwarna putih dan tebal dengan pertumbuhan miselium yang relatif lambat, dan pola sebaran miselium yang konsentris. Sruktur hifa yang terbentuk bersepta dan hialin serta tidak ditemukan konidia. Selanjutnya, Isolat CKB3 berwarna putih kecoklatan. Tekstur koloninya adalah kasar dan tipis. Pertumbuhan miseliumnya cepat dengan pola sebaran konsentris. Sruktur hifa yang terbentuk bersepta dan hialin serta tidak ditemukan konidia. Adapun Isolat CKB4 berwarna putih dengan tekstur koloni kasar dan tipis. Pertumbuhan miseliumnya cepat dengan pola sebaran konsentris. Sruktur hifa yang terbentuk adalah bersepta dan hialin serta tidak ditemukan konidia.

\section{Cendawan Endofit Indigenous Asal Batang}
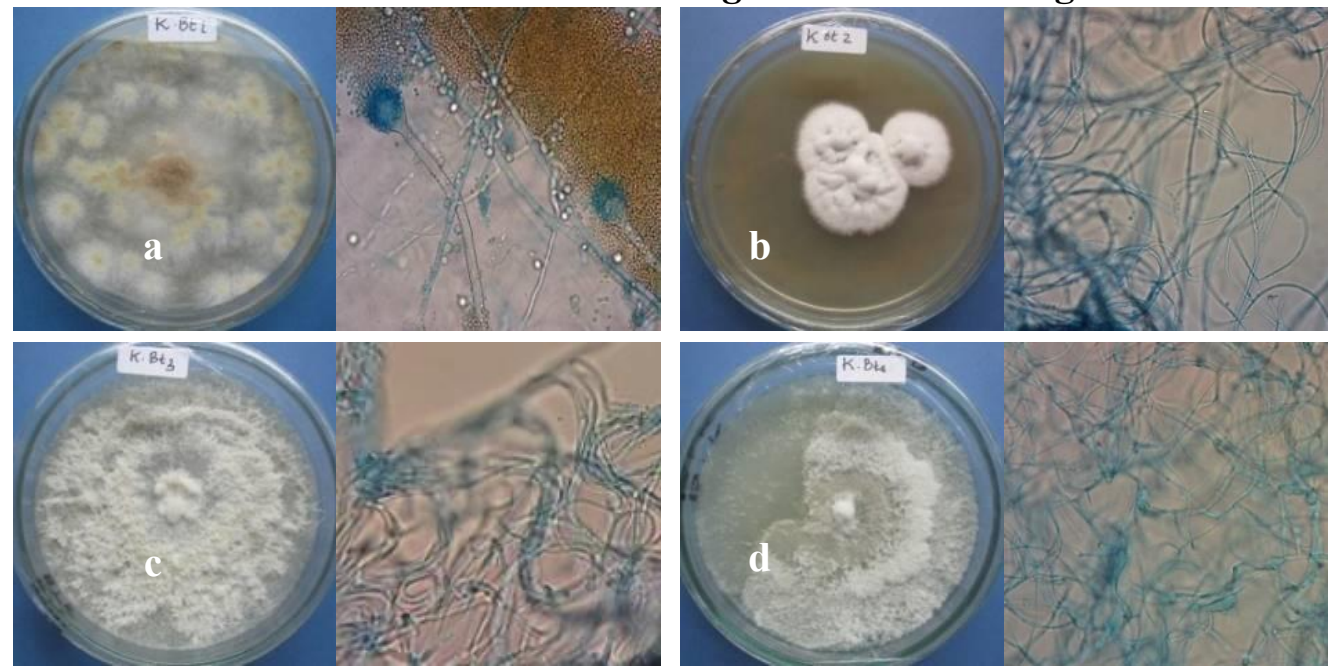

Gambar 2. Penampakan Koloni Isolat Cendawan Endofit Asal Batang: (a) Isolat CKB1, (b) Isolat CKB2, (c) Isolat CKB3, dan (d) Isolat CKB4

\section{Cendawan Endofit Indigenous Asal Daun dan Tanah Perakaran (Rhizosfer)}
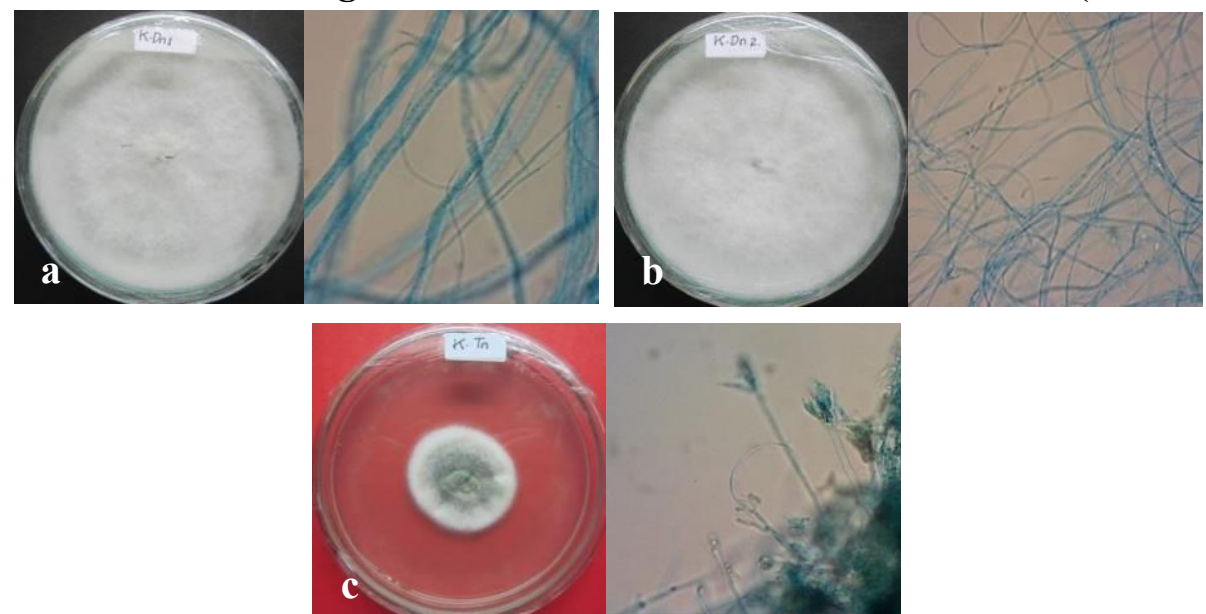

Gambar 3. Penampakan Koloni Isolat Cendawan Endofit Asal Daun dan Tanah Rhizosfer: (a) Isolat CKD1, (b) Isolat CKD2, dan (c) Isolat CKT 
Isolat CKD1 dan CKD2 merupakan hifa steril dengan pertumbuhan yang sangat cepat hingga telah menutupi seluruh permukaan Media PDA pada 3 HSI. Koloni 2 cendawan ini berwarna putih. Adapun miselium tumbuh membentuk koloni yang luas dan halus seperti kapas dengan pola sebaran konsentris. Sruktur hifa yang terbentuk tidak bersepta serta tidak ditemukan konidia. Sekilas isolat CKD2 terlihat persis dengan isolat CKD1, namun perbedaannya adalah isolat CKD2 memiliki koloni yang lebih tebal dan kompak.

Isolat CKT diidentifikasi sebagai Penicillium sp. Koloni cendawan ini berwarna hijau dikelilingi warna putih. Tekstur koloni seperti kapas dan granular. Hal ini sesuai dengan Agusta (2009) yang menyatakan bahwa pada medium PDA, cendawan endofit Penicillium sp. akan membentuk koloni berwarna hijau tua dengan warna putih di sekelilingnya. Pola sebaran miseliumnya adalah konsentris dengan pertumbuhan miselium yang lambat. Struktur hifa yang terbentuk adalah bersepta. Purwantisari and Hastuti (2012) melaporkan bahwa Penicilium sp. biasanya bersepta, memiliki badan buah yang berbentuk seperti sapu diikuti sterigma, dan konidia yang tersusun seperti rantai.

\section{B. Karakterisasi dan Identifikasi Bakteri Endofit Indigenous}

Eksplorasi bakteri endofit indigenous pada tanaman kedelai menghasilkan 3 isolat yang berasal dari bagian polong, akar, dan tanah. Isolat bakteri tersebut diberi kode yang diawali dengan huruf BK (bakteri kedelai) dan diikuti kode asal jaringan beserta nomor. Karakterisasi bakteri endofit meliputi morfologi koloni (bentuk, elevasi, bentuk tepian, permukaan dan warna koloni), dan morfologi sel yang mencakup bentuk sel dan pewarnaan Gram (Tabel 4).

Tabel 4. Karakteristik Morfologi Koloni dan Sel Bakteri Endofit Indigenous

\begin{tabular}{|c|c|c|c|c|c|c|}
\hline \multirow[b]{2}{*}{ Kode Isolat } & \multicolumn{4}{|c|}{ Morfologi Koloni } & \multicolumn{2}{|c|}{ Morfologi Sel } \\
\hline & $\begin{array}{l}\text { Bentuk } \\
\text { Koloni }\end{array}$ & Elevasi & Bentuk Tepian & $\begin{array}{c}\text { Warna } \\
\text { Koloni }\end{array}$ & Bentuk Sel & Sifat Gram \\
\hline BKP & $\begin{array}{l}\text { Sirkular } \\
\text { (teratur) }\end{array}$ & $\begin{array}{c}\text { Flat } \\
\text { (Datar) }\end{array}$ & $\begin{array}{c}\text { Serrate } \\
\text { (Tepian bergerigi) }\end{array}$ & $\begin{array}{l}\text { Kuning } \\
\text { Pucat }\end{array}$ & $\begin{array}{c}\text { Basil } \\
\text { (Batang) }\end{array}$ & Negatif \\
\hline BKA & $\begin{array}{l}\text { Sirkular } \\
\text { (teratur) }\end{array}$ & $\begin{array}{c}\text { Flat } \\
\text { (Datar) }\end{array}$ & $\begin{array}{c}\text { Entire } \\
\text { (Tepian rata) }\end{array}$ & $\begin{array}{l}\text { Kuning } \\
\text { Pucat }\end{array}$ & $\begin{array}{c}\text { Basil } \\
\text { (Batang) }\end{array}$ & Negatif \\
\hline BKT & $\begin{array}{l}\text { Irregular } \\
\text { (Tidak } \\
\text { beraturan) }\end{array}$ & $\begin{array}{c}\text { Flat } \\
\text { (Datar) }\end{array}$ & $\begin{array}{c}\text { Entire } \\
\text { (Tepian rata) }\end{array}$ & $\begin{array}{l}\text { Kuning } \\
\text { Pucat }\end{array}$ & $\begin{array}{c}\text { Basil } \\
\text { (Batang) }\end{array}$ & Negatif \\
\hline
\end{tabular}

Keterangan: $\mathrm{BKP}=$ Isolat bakteri asal polong, $\mathrm{BKA}=$ Isolat bakteri asal akar, $\mathrm{BKT}=$ Isolat bakteri asal tanah

Pewarnaan Gram pada isolat bakteri bertujuan melihat perbedaan morfologi dan memudahkan identifkasi bakteri menjadi dua kelompok, yaitu bakteri Gram positif dan bakteri Gram negatif. Prinsip dasar dari metode pewarnaan gram adalah kemampuan dinding sel menyerap zat warna dasar setelah pencucian dengan alkohol. Sel bakteri yang bisa mempertahankan warna biru gelap atau ungu dari pewarna primer setelah dilakukan pencucian digolongkan ke dalam bakteri gram positif.

Sementara bakteri Gram negatif akan melepas zat warna (kristal violet) yang berwarna biru gelap atau ungu tersebut setelah dicuci dengan alkohol, lalu menyerap zat warna terakhir yang 
diberikan yaitu safranin sehingga menjadi berwarna merah. Chaelani (2010) melaporkan bahwa hasil pewarnaan Gram adalah warna ungu sampai biru hitam untuk bakteri Gram positif, dan berwarna merah untuk bakteri Gram negatif.

Perbedaan warna pada bakteri gram positif dan gram negatif menunjukkan adanya perbedaan struktur dinding sel antara dua jenis bakteri tersebut. Sastrahidayat (2011) menyatakan bahwa bakteri Gram positif memiliki dinding sel yang terdiri atas lapisan peptidoglikan yang tebal dan asam teichoic. Sementara bakteri gram negatif memiliki lapisan luar lipopolisakarida, terdiri atas membran dan lapisan peptidoglikan yang tipis terletak pada periplasma (di antara lapisan luar dan membran sitoplasmik). Hasil penelitian menunjukkan bahwa 3 isolat bakteri yang diuji termasuk ke dalam golongan bakteri Gram negatif. Penampakan secara makroskopis dan mikroskopis serta deskripsi masing-masing isolat bakteri endofit disajikan pada Gambar 4 berikut ini.
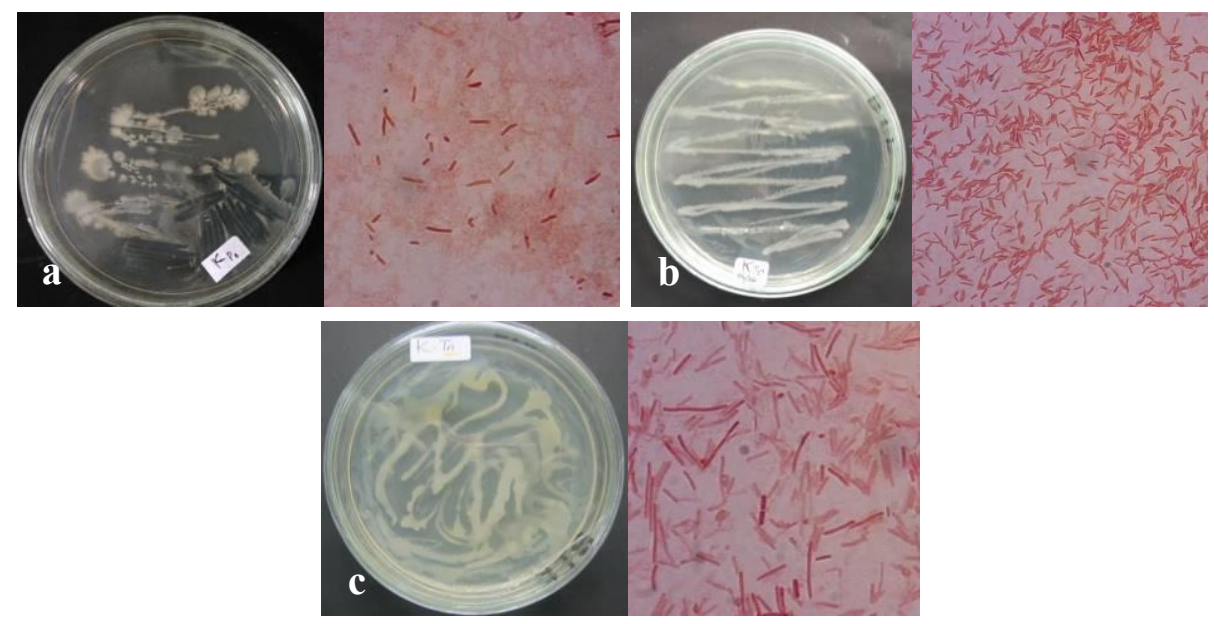

Gambar 4.Penampakan Isolat Bakteri pada Media NA dan secara Mikroskopis perbesaran 100x: (a) Isolat BKP, (b) Isolat BKA, dan (c) Isolat BKT

Isolat BKP memiliki koloni berbentuk teratur dan elevasi datar dengan tepian bergerigi. Adapun Isolat BKA berbentuk teratur dan elevasi datar dengan tepian rata. Sementara Isolat BKT berbentuk tidak beraturan dan elevasi datar dengan tepian rata. Ketiga isolat ini memiliki koloni berwarna kucing pucat pada media NA. Bentuk sel bakteri ini adalah basil (batang) dengan ujung bundar. Hasil pengamatan mikroskopis menunjukkan sel bakteri Isolat BKP dan BKT bersifat non-motil dengan penataan tunggal atau monobasil, sedangkan Isolat BKA bersifat motil dengan penataan berpasangan atau diplobasil. Hasil pewarnaan Gram menunujukkan bahwa ketiga isolat bakteri ini merupakan bakteri Gram negatif.

\section{Uji Hipovirulensi}

Uji Hipovirulensi merupakan satu metode pengujian apakah mikroba endofit yang berasal dari berbagai jaringan tanaman bersifat virulen atau hipovirulen. Menurut Nurhayati (2010), virulensi didefinisikan sebagai derajat patogenitas suatu mikroba terhadap inangnya, sedangkan virulen adalah sifat mikroba yang sangat patogenik (menimbulkan penyakit). Safitri (2017) menambahkan 
bahwa dengan kata lain, hipovirulen merupakan sifat patogen yang virulensinya rendah.

Uji hipovirulensi dilakukan pada benih mentimun. Supriyanto et al. (2009) melaporkan bahwa tanaman ini lebih responsif dan sensitif dibanding tanaman lain terhadap perubahan kondisi medium tumbuh, sehingga pemberian isolat cendawan endoft dapat langsung mempengaruhi pertumbuhannya. Berdasarkan hasil uji hipovirulensi, terdapat 7 isolat cendawan endofit yang bersifat hipovirulen dan 4 isolat cendawan endofit bersifat virulen.

Tabel 5. Hasil Uji Hipovirulensi terhadap 11 Cendawan Endofit Indigenous

\begin{tabular}{ccc}
\hline $\begin{array}{c}\text { Kode } \\
\text { Isolat }\end{array}$ & DSI* & $\begin{array}{c}\text { Dugaan } \\
\text { Hipovirulen / } \\
\text { Viirulen }\end{array}$ \\
\hline CKA1 & 1.33 & $\begin{array}{c}\text { Hipovirulen } \\
\text { Virulen }\end{array}$ \\
CKA2 & 3.67 & Virulen \\
CKA3 & 3.33 & Hipovirulen \\
CKA4 & 1.33 & Hipovirulen \\
CKB1 & 1.33 & Hipovirulen \\
CKB2 & 1.33 & Hipovirulen \\
CKB3 & 0.00 & Hipovirulen \\
CKB4 & 0.00 & Hipovirulen \\
CKD1 & 1.33 & Virulen \\
CKD2 & 3.33 & Virulen \\
CKT & 3.33 & \\
\hline
\end{tabular}

Keterangan: *) Disease Severity Index (DSI) adalah indeks keparahan penyakit yang dinilai dengan ketentuan: $0=$ sehat dan tidak ada infeksi pada hipokotil, 1 = satu atau dua bercak coklat muda $<0.25 \mathrm{~cm}, 2=$ bercak coklat muda $<0.5 \mathrm{~cm}$ dan area kebasahan $<10 \%$ pada hipokotil, $3=$ bercak coklat muda sampai tua $>1.0 \mathrm{~cm}$ dan kemudian bergabung dengan bercak lainnya dan daerah kebasahan $10 \%<\mathrm{x}<100 \%$ pada hipokotil (daun belum layu dan hipokotil masih tegar dan putih, $4=$ hipokotil bercak hitam, daun layu, dan bibit mati (Cardoso dan Echandi dalam Worosuryani, 2006).

Nilai DSI isolat cendawan yang bersifat hipovirulen adalah 0.00 dan 1.33 . Nilai DSI 0.00 berarti semua individu benih mentimun yang ditumbuhkan bersama isolat cendawan tersebut mampu tumbuh sehat tanpa ada infeksi. Adapun isolat-isolat dengan nilai DSI 1.33 pada hasil uji ini adalah isolat yang menyebabkan satu dari tiga individu benih uji mengalami gejala penyakit atau infeksi ringan pada hipokotilnya. Hal ini berarti isolat dengan nilai ini masuk dalam kategori moderat dan masih bersifat hipovirulen. Hasil uji hipovirulensi menunjukkan bahwa isolat cendawan yang bersifat hipovirulen adalah isolat yang tidak memberikan pengaruh negatif terhadap pertumbuhan bibit mentimun, bahkan pertumbuhannya lebih baik dibandingkan kontrol.

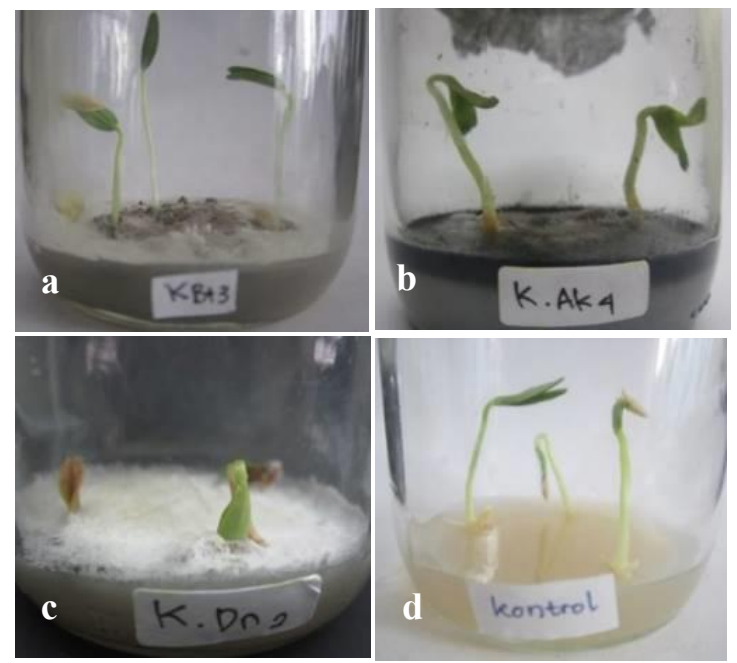

Gambar 5.Hasil Uji Hipovirulensi isolat cendawan endofit terhadap benih mentimun: (a) isolat hipovirulen CKB3 dengan nilai DSI 0.00, (b) isolat hipovirulen CKA4 dengan nilai DSI 1.33, (c) isolat virulen CKD2 dengan nilai DSI 3.33, dan (d) control

Tabel 6. Hasil Uji Hipovirulensi Terhadap Bakteri Endofit Indigenous

\begin{tabular}{ccc}
\hline Kode Isolat & DSI* & $\begin{array}{c}\text { Dugaan } \\
\text { Hipovirulen / } \\
\text { Viirulen }\end{array}$ \\
\hline BKP & 4.00 & Virulen \\
BKA & 4.00 & Virulen \\
BKT & 4,00 & Virulen \\
\hline
\end{tabular}

Keterangan: *) Disease Severity Index (DSI) adalah indeks keparahan penyakit yang dinilai dengan ketentuan: $0=$ sehat dan tidak ada infeksi pada hipokotil, $1=$ satu atau dua bercak coklat muda $<0.25 \mathrm{~cm}, 2=$ bercak coklat muda $<0.5 \mathrm{~cm}$ 
dan area kebasahan $<10 \%$ pada hipokotil, $3=$ bercak coklat muda sampai tua $>1.0 \mathrm{~cm}$ dan kemudian bergabung dengan bercak lainnya dan daerah kebasahan $10 \%<\mathrm{x}<100 \%$ pada hipokotil (daun belum layu dan hipokotil masih tegar dan putih, 4 = hipokotil bercak hitam, daun layu, dan bibit mati (Cardoso dan Echandi dalam Worosuryani, 2006).

Perendaman benih merupakan salah satu teknik aplikasi yang biasa dilakukan dalam menggunakan bakteri endofit. Saputra (2016) menyatakan bahwa perendaman benih dengan suspensi bakteri endofit memungkinkan bakteri masuk ke dalam benih melalui lubang alami. Hasil uji hipovirulensi menunjukkan bahwa perlakuan perendaman suspensi isolat bakteri terhadap benih mentimun menyebabkan benih tidak mampu tumbuh normal. Hal ini berarti isolat bakteri tersebut merupakan isolat virulen. Seluruh sampel benih tidak dapat tumbuh hingga hari ke-14 setelah inkubasi. Berdasarkan Tabel 7, nilai DSI pada seluruh isolat adalah bernilai 4.00, meskipun secara visual pada benih tidak terdapat bercak hitam dan tanda kematian benih. Penampakan hasil uji hipovirulensi bakteri endofit yang dilakukan terhadap benih mentimun di botol kultur dengan media NA dapat dilihat pada Gambar 6 .

Gambar 6 merupakan penampakan uji hipoviruensi pada 14 HSI. Berdasarkan gambar di atas, benih uji dengan perendaman masing-masing isolat bakteri tidak berhasil berkecambah normal (Gambar 6a, b, c) jika dibandingkan dengan perlakuan kontrol (Gambar 6d). Meski begitu, tidak pula terdapat tandatanda benih mengalami kematian, misalnya warna benih berubah menjadi hitam atau kemunculan lendir di sekitar benih. Hal ini diduga sebab bakteri telah masuk ke dalam cadangan makanan (endosperm) benih mentimun yang menyebabkan benih tidak berhasil berkecambah. Irawati et al. (2017) menjelaskan kecambah dengan pertumbuhan normal adalah kecambah dengan perkembangan sistem akar, hipokotil, $\quad$ plumula, dan kotiledon/endosperm yang sempurna tanpa kerusakan dan kelainan pada jaringanjaringannya.
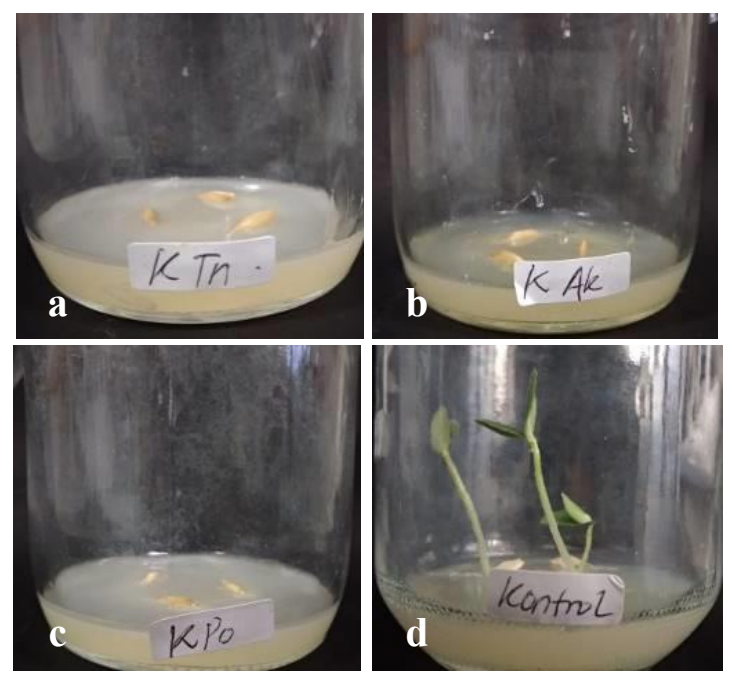

Gambar 6.Hasil Uji Hipovirulensi isolat bakteri endofit terhadap benih mentimun: (a) isolat BKTN, (b) isolat BKAK, (c) isolat BKPO dan (d) kontrol

Berdasarkan data di atas, bakteri endofit diduga mengalami mutasi karena sudah tidak mendapatkan asupan metabolit tertentu lagi sebagai asupan untuk aktivitas metabolisme setelah dipisahkan dari sel inang asalnya. Kusnadi (2012) melaporkan bahwa mutasi dapat dipengaruhi oleh keadaan lingkungan yang tidak normal. Gen bakteri yang mengalami mutasi atau perubahan pada satu atau lebih basa DNAnya disebut Mutan. Salah satu tipe mutan bakteri adalah yang mempunyai defisiensi nutrisi, yaitu membutuhkan medium yang lebih kompleks untuk tumbuhnya ketimbang biakan aslinya. Sholikhin (2014) menyatakan bahwa meskipun bakteri endofit diketahui sebagai agens hayati yang mampu memacu pertumbuhan tanaman (plant growth promoter), tidak semua bakteri endofit memiliki efek yang demikian. Damayanti (2010) melaporkan hasil penelitiannya bahwa perlakuan bakteri endofit pada tanaman tomat tidak memberikan pengaruh yang nyata terhadap 
pertumbuhan tinggi tanaman. Menurut Sholikhin (2014), hal ini disebabkan oleh adanya interaksi yang kompleks baik yang terjadi antara bakteri endofit dengan tanaman inang, patogen, maupun dengan mikroorganisme lain di dalam tanaman.

\section{KESIMPULAN}

Berdasarkan penelitian ini, dapat disimpulkan beberapa hal sebagai berikut:

1. Cendawan endofit berhasil diisolasi dari seluruh jaringan tanaman, kecuali polong. Keragaman cendawan endofit tertinggi terdapat pada jaringan akar dan batang, yaitu masing-masing berjumlah 4 isolat. Identitas cendawan endofit yang berhasil diidentifikasi antara lain adalah Fusarium sp., Verticilllum sp., Alternaria sp., Aspergillus sp., Penicillium sp., dan 6 isolat lainnya yang tidak dapat terindentifikasi. Adapun bakteri endofit hanya terisolasi dari jaringan polong, akar, dan tanah. Seluruh bakteri merupakan golongan bakteri Gram negatif.

2. Berdasarkan hasil Uji Hipovirulensi, terhadap 7 isolat cendawan endofit indigenous yang masuk dalam kategori hipovirulen dan 4 isolat lainnya bersifat virulen. Sedangkan semua isolat bakteri endofit yang diuji menunjukkan kategori virulen.

\section{DAFTAR PUSTAKA}

Agusta, A. (2009). Biologi dan Kimia 镐 Jamur Endofit. Bandung: ITB Bandung.

Ahmad, R. Z. (2013). Kapang 钢 Paecilomyces lilacinus dan Verticillium chlamydosporium Sebagai Pengendali Hayati Fasciolosis. Wartazoa, 23(3), 135141.

Ata, H., Papuangan, N., \& Bahtiar. (2016).

县 Identifikasi Cendawan Patogen pada Tanaman Tomat (Solanum lycopersicum L). Bioedukasi, 4(2), 541-550.
Barnett, H. L., \& Hunter, B. B. (1998). 副 Illustrated Genera of Imperfect Fungi. Minnesota: APS Press.

Berg, G. (2009). Plant-microbe E interactions promoting plant growth and health: perspectives for controlled use of microorganisms in agriculture. Applied Microbiology and Biotechnology, 84(1), 11-18. https://doi.org/10.1007/s00253-0092092-7

Chaelani, S. R. (2010). Metode Penelitian 尌 Penyakit Tumbuhan. Malang: Universitas Brawijaya Press.

Damayanti, I. (2010). Seleksi Dan Earakterisasi Bakteri Endofit Untuk Menekan Kejadian Penyakit Layu Bakteri (Ralstonia Solanacearum) Pada Tanaman Tomat (Skripsi, Institut Pertanian Bogor).

El-Maghraby, O. M. O., Soltan, S. M., El Mohammed, R. M., \& Mohammed, M. M. (2013). Endophytic fungi of three leguminous plant roots in Egypt. Journal of Basic \& Applied Mycology (Egypt), 4, 59-68.

Hardaningsih, S. (2012). Eudarluca caricis, 尌 Mikoparasit yang Berpotensi Menekan Pertumbuhan Jamur Karat Pada Tanaman Kacang-Kacangan. Prosiding Seminar Hasil Penelitian Tanaman Aneka Kacang Dan Umbi.

Irawati, A. F. C., Mutaqin, K. H., 尌 Suhartono, M. T., Sastro, Y., Sulastri, N., \& Widodo, N. (2017). Eksplorasi dan Pengaruh Cendawan Endofit yang Berasal dari Akar Tanaman Cabai Terhadap Pertumbuhan Benih Cabai Merah. Jurnal Hortikultura, 27(1), 105. https://doi.org/10.21082/jhort.v27n1 .2017.p105-112

Istifadah, N., \& Sari, I. P. (2017). Efek E Jamur Endofit Asal Daun dan Akar Kacang Tanah terhadap Pertumbuhan dan Penghambatan 
Patogen Inangnya. Jurnal Mikologi Indonesia, 1(2), 61-69.

Kusnadi. (2012). Common Text 钢 Mikrobiologi. Bandung: Universitas Pendidikan Indonesia.

Nurhayati. (2010). Senarai Istilah-Istilah 尌 Mikologi. Palembang: Universitas Sriwijaya.

Purwantisari, S.-, \& Hastuti, R. B. (2012).

Isolasi dan Identifikasi Jamur Indigenous Rhizosfer Tanaman Kentang dari Lahan Pertanian Kentang Organik di Desa Pakis, Magelang. Bioma: Berkala Ilmiah Biologi, 11(2), 45. https://doi.org/10.14710/bioma.11.2. 45-53

Riniarsi, D. (2016). Outlook Komoditas 尌 Pertanian Tanaman Pangan Kedelai.

Safitri, D. A. (2017). Pengujian 尌 Antagonisme Bakteri Endofit Terhadap Patogen Penting Tanaman Nanas (Ananas comosus L.) (Skripsi, universitas Lampung).

Sanjaya, Y., Nuhaeni, H., \& Halima, M. (2010). Isolasi, Identifikasi, dan Karakterisasi Jamur Entomopatogen Dari Larva Spodoptera Litura (Fabricius). Bionatura: Jurnal IlmuIlmu Hayati Dan Fisik, 12(3), 136141.

Saputra, M. (2016). Aplikasi Bakteri Endofit Dengan Metode Perendaman Benih, Penyiraman Pada Tanah, Dan Pencelupan Akar Terhadap Meloidogyne spp Pada Tanaman Tomat (Skripsi, Institut Pertanian Bogor).

Sastrahidayat, I. R. (2011). Fitopatologi 㖵 (Ilmu Penyakit Tumbuhan). Malang: Universitas Brawijaya Press.

Sholikhin, I. (2014). Keefektifan Bakteri Endofit Sebagai Agens Hayati Terhadap Penyakit Hawar Daun
Bakteri (Xanthomonas Oryzae Pv. Oryzae) Pada Padi (Skripsi, Institut Pertanian Bogor).

Sneh, B., Yamoah, E., \& Stewart, A. 䪺 (2004). Hypovirulent Rhizoctonia spp. isolates from New Zeland Soils Protected Radish Seedlings Against damping-off caused by Rhizoctonia solani. New Zealand Plant Protection, 57, 54-58.

Sudantha, I. M. (2009). Pemanfaatan EQ Jamur Endofit dan Saprofit Antagonis Sebagai Agens Pengendali Hayati Patogen Tular Tanah Untuk Meningkatkan Kesehatan Dan Hasil Tanaman.

Supriyanto, Priyatmojo, A., \& Arwiyanto, T. (2009). Penapisan PGPF Untuk Pengendalian Penyakit Busuk Lunak Lidah Buaya (Aloe vera) di Tanah Gambut. Jurnal Perlindungan Tanaman Indonesia, 15(2), 71-82.

Trizelia, Winarto, \& Tanjung, A. (2017). E Keanekaragaman Jenis Cendawan Endofit pada Tanaman Gandum (Triticum aestivum) yang Berpotensi sebagai Bioinsektisida. Prosiding Seminar Nasional Masyarakat Biodiversitas Indonesia. Prosiding Seminar Nasional Masyarakat Biodiversitas Indonesia (Pros Sem Nas Masy Biodiv Indon), 433-437.

Waruwu, A., Soekarno, B., \& Munif, A. 尌 (2016). "Metabolite of Endophytic Fungi Isolated from Rice as an Alternative to Control Seed-borne Pathogenic Fungi on Rice ". Jurnal Fitopatologi Indonesia, 12(2), 5361. https://doi.org/10.14692/jfi.12.2.53

Worosuryani, C., Priyatmojo, A., \& EQ Wibowo, A. (2006). Uji Kemampuan Jamur Tanah yang diisolasi dari lahan pasir sebagai PGPF (Plant Growth Promoting Fungi). Agrosains, 19(2), 179-191. 
Yulianti, T. (2012). Menggali Potensi

Endofit untuk Meningkatkan

Kesehatan Tanaman Tebu

Mendukung Peningkatan Produksi

Gula. Perspektif, 11(2), 113-123. 